\title{
The role of insects in the spreading of pathogens and development of diseases on sunflower in the Krasnodar region of the Russian Federation
}

\author{
Maria Iwebor ${ }^{1, *}$, Sergey Frolov ${ }^{1}$, Irina Frolova $^{1}$, Olga Shabaldas $^{2}$, and Maria Chernikova $^{2}$ \\ ${ }^{1}$ Armavirskaya experimental station of VNIIMK, 352925, Central Farm of VNIIMK experimental \\ station, Armavir, Krasnodar region, Russia \\ ${ }^{2}$ Stavropol State Agrarian University, 355017, 12 Zootekhnicheskiy Ln, Stavropol, Russia
}

\begin{abstract}
The insects play a major role in the spreading of pathogens and the development of diseases on sunflower in the Krasnodar region of the Russian Federation. We established connections between the most common insects and phytopathogenic microorganisms. The main components of an integrated plant protection system are considered. When deciding on the usage of insecticides it is necessary to take into account not only direct, but also indirect insect damage (the development of plant diseases after damage, and as a result, a yield decrease, contamination of food and feed with dangerous mycotoxins).
\end{abstract}

\section{Introduction}

Sunflower (Helianthus annuus L.) is one of the main oil crops in the world. The Russian Federation (RF) is among the world leaders in the production of sunflower oilseeds. In our country, the sunflower is one of the leading agricultural crops: it occupies more than $10 \%$ of planted acreage, which is about 7-8.5 million hectares per year. The Krasnodar region is one of the main regions of the Russian Federation that cultivate sunflower.

Diseases and pests (in the Krasnodar region, it is mainly insects) can significantly reduce the yield and quality of sunflower oilseeds. Among the large number of organisms infecting sunflower plants, there are several the most harmful. Their composition can differ from country to country, which is determined, first of all, by agro-climatic conditions. The biological characteristics and harmfulness of many pests and pathogens are well studied; there were developed recommendations on effective methods of their control. However, there were basically no studies on the interaction of pathogens and insects on sunflower, although it is known that the insects can be vectors of pathogens and/or cause injuries to plants that become a portal of entry of infection.

More than 700 plant diseases are recognized as vector-borne and have a negative effect on plant health and food security worldwide [1]. Entomochory in plant pathology is a multidimensional phenomenon that includes the transfer, reservation, reproduction,

\footnotetext{
*Corresponding author: maria-iwebor@mail.ru
} 
preservation, and introduction of a phytopathogenic infection into plant tissues and organs, fruits, and seeds by insects [2]. However, the role of insects in the pathogenesis of diseases is usually dismissed or underestimated, although often pathogens are not able to spread and penetrate the plants in the absence of an insect. Insects can transmit pathogenic microorganisms from plants to plants of one field and other fields, at distances from several meters to many kilometers. Many plant diseases become much more serious and harmful in the presence of insects both in the field conditions and in harvested plant products. It was established that the direct or indirect participation of insects can be responsible for about $30-40 \%$ of losses caused by plant diseases [3].

Almost all types of phytopathogens can spread entomochorically, being connected with insects in pathological processes by various forms of relations. Cherpakov (2013) identified five such forms: 1 . Neutral, when insects are mechanical carriers of the infective matter, moving from infected plants to healthy ones; 2. Different forms of symbiosis: insects carry the pathogen in themselves, being the containers for its accumulation. Phytopathogenic and phytosaprophytic bacteria develop in the body of an insect, phytoviruses replicate using its cells, the spores of phytopathogenic fungi accumulate in cavities and on the body of insect; 3 . Bacteria and viruses pass through the mouthparts and the gastrointestinal tract of piercing-sucking insects and, without lingering in the body, enter the unaffected plant tissues through the excretory systems. The binary division of bacteria and replication of viruses take place in the saliva of an insect and the processed sap of the infected plant; 4. The damage caused by insects contributes to the penetration of a microorganism into the host plant organism; 5. Insects transfer saprophytic microflora, forming associations of saprotrophs that are not related to the onset of a pathological process but continue the process of destruction of plant tissues [4]. Although the author presented these models for woody plants, they are applicable to other plant types.

Many authors in their works consider the systems of interactions between insects, phytopathogens and plants as more complex, taking into account the secreted volatile organic compounds $[5,6]$, beneficial microorganisms [7, 8], abiotic environmental factors [8], and other aspects $[9,10]$. Our reconnaissance work aimed to establish the relation between insects and the most common diseases of sunflower in the Krasnodar region of the RF.

\section{Materials and methods}

The research was carried out in 2018-2020. We surveyed the sunflower fields in the Krasnodar region and recorded diseases and insects, took samples of infected plants and insects for laboratory analysis. The plants were examined for the presence and types of insect damage using a magnifying glass. Parts of the infected plants were placed in a moist chamber and on agar medium to isolate microflora and identifying it further, using standard methods of experimental phytopathology. We made identifications by using identifiers of insects [11-13] and fungi $[14,15]$. Bacterial infections were diagnosed with the help of publications of Borodin et al. (2012) [16], Harveson et al. (2018) [17]. The legitimacy of the names was checked against global databases [13, 18-20].

Insects of different species were examined using a microscope to detect microflora on the body surface of their bodies. After that the insects were immersed one by one in separate glass tubes with $10 \mathrm{ml}$ of sterile water, vigorously shaken for several minutes to wash off the surface microflora, the resulting suspension was inoculated into Petri dishes with agar nutrient medium PGA (potato-glucose agar) without adding antibiotics and with antibiotic streptomycin.

We obtained pure cultures of isolated fungi and bacteria, identified them by cultural and morphological characteristics using a microscope. Pathogenicity of isolates was tested by 
inoculating sunflower plants of cultivars R-453 (Rodnik) and VNIIMK 8883: of fungi of the genus Alternaria - using the methods described by Iwebor et al. (2014) [21] and Fusarium - using the method proposed by Zazzerini and Tosi (1987) [22], bacteria according to Baştaş et al. (2009) [23]. When spores of rust (Puccinia sp.) were in the washout from insects, we added up to $200 \mathrm{ml}$ of sterile water to the washout, mixed it thoroughly, and infected the plants according to the method described by Araslanova et al. (2019) [24]. Control plants were sprayed with sterile water or pieces of clean culture medium were applied. In the case of manifestation of disease symptoms on the plants, the pathogen was isolated and identified to complete the Koch triad.

\section{Results and discussion}

During the years of our research, we observed on sunflower not only phytophages of this agricultural crop but also pests polytrophic (predominantly) and of other crops, pollinators, predators (ladybugs, wasps, lacewings, etc.), and other insects (ants, flies, etc.). The most common phytophages were owlet moths (turnip moth - Agrotis segetum Denis \& Schiffermüller, cotton bollworm - Helicoverpa armigera Hbn., marbled clover - Heliothis viriplaca Hufnagel., etc.), European sunflower moth (Homoeosoma nebulellum Denis \& Schiffermüller), beet webworm moth (Loxostege sticticalis L.), Heteroptera bugs (sloe bug - Dolycoris baccarum L., tarnished plant bug - Lygus pratensis L., etc.), weevils, aphids, leafhoppers and others, noted in the region earlier [25, 26].

The most common sunflower diseases were Fusarium, bacteriosis, Rhizopus head rot, charcoal rot (Macrophomina phaseolina (Tassi) Goid), gray mold (Botryotinia fuckeliana (deBary) Whetzel. - anamorphic stage of Botrytis cinerea Pers.), downy mildew (Plasmopara halstedii (Farl.) Berl. et de Toni), Alternaria blight (Alternariaster helianthi (Hansford) Tubaki et Nishihara, Alternaria sp.), Phoma black stem (Plenodomus lindquistii (Frezzi) Gruyter, Aveskamp \& Verkley), Phomopsis stem canker (Phomopsis (Diaporthe) helianthi Munt.-Cvetk., Mihaljč. \& M. Petrov), Verticillium infection (Verticillium dahliae Kleb.) and rust (Puccinia helianthi Schwein.), while Sclerotinia basal stalk rot (Sclerotinia sclerotiorum (Lib.) de Bary), powdery mildew (Golovinomyces sp.) and some others were less common.

About $40 \%$ of plant samples infected with the fungi Fusarium sp., M. phaseolina, B. cinerea, $V$. dahlie and bacteria had insect-damaged basal and underground parts. Judging by the nature of the damage, they were mainly caused at the early stages of development of sunflower plants by the wireworms (larvae of click beetles) - Elateridae family, by false wireworms (the larvae of darkling beetle) - Tenebrionidae family, and by turnip moth.

Occasionally, the larvae of sunflower barbell (Agapanthia (Epoptes) dahlii muellneri Reit.) and tumbling sunflower beetle (Mordellistena parvula Gyll.) on sunflower stems were found. Fusarium sp., Alternaria sp., saprotrophic fungi (Aspergillus sp., Penicillium sp.), and bacteria were associated with them. The same microorganisms were associated with damage by European corn borer (Ostrinia nubilalis Hubner), in rare cases the development of Phoma black stem, and often Rhizopus head rot (with injuries to the upper parts of a stem) were observed.

In the case of damage to leaves and heads, the role of insects in the disease development was the most obvious. During our research, we found that several diseases of sunflower plants were directly related to insects, especially those caused by the smallspored Alternaria species. The small-spored Alternaria species are the causative agents of Alternaria blight, which can also be caused by $A$. helianthi. Previously, it was established the differences between these pathogens by several characteristics, including the symptoms of the disease and the ability to infect healthy sunflower plants [21]. In this research the small-spored Alternaria species were also isolated from dark brown spots of varying size 
on the leaf blades, spathes, and the head backside; in some cases, up to $80 \%$ of the head was affected. These symptoms developed precisely because of insect bites, mainly with a sucking or piercing-sucking mouthpart: bugs, aphid, leafhoppers, and thrips. Evidently, the exertion of these insects, which they introduce into plants with saliva, contributes to the development of the small-spored Alternaria on a sunflower at the bite sites. In case of artificial infection of sunflower plants, none of the 15 isolates of the smallspored Alternaria sp., isolated from the affected parts of sunflower plants, as well as washed out from insects, did not cause characteristic symptoms of the disease; in some cases, slight necroses at the sites of punctures and scratches were observed, but it was noted the same on the control plants. In case of infection with $A$. helianthi, there were characteristic symptoms - spots on the leaves and stems, the pathogen emitting from the spots. These results are consistent with those obtained in the previous research [21].

The development of diseases on sunflower heads also significantly depended on insects. In our research, Rhizopus sp. and B. fuckeliana, causing Rhizopus head rot and Botrytis head rot (respectively), as well as bacteriosis, were most often associated with the damage by the cotton bollworm ( $H$. armigera), as well as by the marbled clover and sunflower moth. Botrytis head rot manifested itself mainly in wet weather on sowings of late-ripening cultivars and hybrids of sunflower.

As the experiment showed, insects collected on sunflower (not only phytophages, but also ants, wasps, flies, etc.) most often transferred spores and fragments of mycelium of the small-spored Alternaria species, Fusarium, bacteria, and less often A. helianthi on the surface of their bodies, in the sunflower ripening period, the transfer included Rhizopus and Puccinia. We observed these microorganisms on insect bodies and in washouts under a microscope; colonies of facultative saprotrophs grew on nutrient media. We did not identify all microorganisms; some of them we subcultured, obtaining, and identifying monosporous isolates. Several isolates of each identified genera of fungi and bacteria were tested for pathogenicity to sunflower. In addition to $A$. helianthi, it was established pathogenicity for $P$. helianthi, five out of nine Fusarium isolates, and nine out of fifteen bacterial isolates.

The bacteria isolated from plants and insect bodies belonged to different genera. We identified them as Pectobacterium carotovorum (Jones) Waldee (syn. Erwinia carotovora (Jones) Holland), Pseudomonas syringae van Hall, Xanthomonas arboricola Vauterin et al. and Rhizobium radiobacter (Beijerinck and van Delden) Young et al. In recent years, bacteriosis has become widespread in the region on many crops, including sunflower. Bacteria infect plants systematically, usually causing characteristic symptoms: spots, ulcers, deformations, and exudate. Bacterial secretions attract various insects, and mostly not phytophages. These are mainly flies, wasps, ants, ladybugs, bees. We noted that the presence of flies on seemingly healthy sunflower plants, the insects with unique sense organs (touch, smell, taste), indicates an asymptomatic course of bacteriosis.

The results of our research demonstrate the very important role of insects in the development of a complex of diseases on sunflower sowings. Even in cases where direct damage (directly from injuries caused by insects) is insignificant, it is necessary to consider the indirect damage - from diseases that have developed due to insects. Moreover, some vector-borne microorganisms (for example, Alternaria, Fusarium, Aspergillus, and Penicillium), contaminate products and fodder, emitting toxins dangerous for humans and animals [27].

The cumulative damage caused by pests can be minimized. Pest control tools include a variety of methods, of which pesticides are just one possible tool for pest control and their use should be considered after careful monitoring. The integrated plant protection system is needed in rational, highly productive, environmentally safe sunflower production. This system should begin with the choice of soil cultivation methods, the application of micro and macro fertilizers, observation of crop rotation and optimal sowing and harvesting dates, 
selection of varieties range, and the quality of seed material. In the realities of modern life, the crop resistance to the main harmful organisms is one of the essential links in its successful cultivation. Biological control methods are also environmentally safe and effective, such as the use of beneficial insects and microorganisms, the use of pheromones and repellents, etc.

\section{Conclusions}

In the Krasnodar region of the Russian Federation, insects play a major role in the spreading of pathogens and the development of diseases on sunflower, especially fungi from the genera Alternaria, Fusarium, Rhizopus, and Puccinia, as well as bacteria. The fungi Alternaria, Fusarium, Aspergillus, and Penicillium, affecting sunflower with the participation of insects, are capable of emitting mycotoxins that are dangerous for humans and animals, contaminating products and fodder.

The rational, highly productive, environmentally safe sunflower production should include an integrated plant protection system.

When deciding on the usage of insecticides it is necessary to take into account not only direct, but also indirect insect damage (the development of diseases on sunflower after insect damage, and as a result, a yield decrease, contamination of food and fodder with dangerous mycotoxins).

\section{References}

1. T.L. Jones, R.F. Medina, Plants (Basel), 9(6), 747 (2020)

2. V.V. Cherpakov, Aktual'nie problemi lesnogo kompleksa, 39, 96 (2014)

3. G.N. Agrios, Encyclopedia of Entomology, 3853 (2008)

4. V.V. Cherpakov, Izvest. S.-P. Lesotechnic. Akad., 207, 71 (2008)

5. M.N. Kondratiev, Yu.S. Larikova, Agrarian science, 2, 57 (2019)

6. L. Simons, T.L. Bultman, T.J. Sullivan, J Chem Ecol. 34(12), 1511 (2008)

7. S.E. Hartley, A.C., Annu. Rev. Entomol., 54, 323 (2009)

8. A. Pineda, M. Dicke, C.M.J. Pieterse, M.J. Pozo, Funct. Ecol., 27, 574 (2013)

9. S.A. Hogenhout, K. Oshima, E.D. Ammar, S. Kakizawa, H.N. Kingdom, S. Namba, Mol Plant Pathol., 9(4), 403 (2008)

10. Z. Mayoral-Peña, R. Álvarez-Martínez, J. Fornoni, E. Garrido, Evolutionary Ecology of Plant-Herbivore Interaction, 135 (2020)

11. G.Ye. Osmolovskiy (ed.), Opredelitel' sel'skokhozyaystvennykh vrediteley po povrezhdeniyam kul'turnykh rasteniy (L., 1976)

12. G.N. Gornostaev, Identifier of insect orders and families of the Russian fauna (Logos, Moscow, 1999)

13. EPPO Global Database (available online) https://gd.eppo.int/ (2020)

14. F.M. Dugan, The Identification of Fungi (APS Press, St. Paul, MN, 2006)

15. V.I. Bilai, Fusarii (Nauk. Dumka, Kiev, 1977)

16. S.G. Borodin, I.A. Kotlyarova, G.A. Tereshenko, N.V. Pashayan, Maslichnye kul'tury. Nauch.-tekh. byul. VNIIMK, 150, 116 (2012)

17. R.M. Harveson, F.M. Mathew, T.J. Gulya, S.G. Markell, C.C. Block, S. Thompson, Plant Health Prog., 19, 82 (2018) 
18. ITIS, the Integrated Taxonomic Information System on-line database (available online) https://www.itis.gov/ (2020)

19. CABI Database Digital resource (available online) https://www.cabi.org/ (2020)

20. MYCOBANK Database (available online) https://www.mycobank.org/ (2020)

21. M.V. Iwebor, S.L. Saukova, T.S. Antonova, N.M. Araslanova, S.A. Ramazanova, Nauka Kubani, 4, 15 (2014)

22. A. Zazzerini, L. Tosi, Plant Dis., 71, 1043, (1987)

23. K.K. Baştaş, H. Hekimhan, S. Maden, M. Tör, Plant Dis., 93(12), 1352 (2009)

24. N.M. Araslanova, T.S. Antonova, M.V. Iwebor, V.I. Khatnyansky, Maslichnye kul'tury, 4(180), 107 (2019)

25. S.A. Semerenko, Zashchita i karantin rasteniy, 3, 22, (2020)

26. S.S. Izhevsky, V.Y. Maslyakov, Russ J Biol Invasions 1, 68 (2010)

27. Y. Luo, X. Liu, J. Li, Food Control, 89, 123 (2018) 